\title{
Late Ordovician solutan echinoderms from the western Tafilalt, Morocco
}

\author{
MARTINA NOHEJLOVÁ ${ }^{1,2 *} \&$ BERTRAND LEFEBVRE $^{1}$
}

(1)

\author{
${ }^{1}$ Univ Lyon, Univ Lyon 1, ENSL, CNRS, LGL-TPE, F-69622, Villeurbanne, France \\ ${ }^{2}$ Czech Geological Survey, Klárov 3, 11821, Praha 1, Czech Republic
}

Orcid identifier: https://orcid.org/0000-0001-7972-8165

*Correspondence: martina.nohejlova@geology.cz

Abstract: In the western Tafilalt area, eastern Anti-Atlas (Morocco), solutan echinoderms are a major faunal element of most echinoderm Lagerstätten occurring within the Lower Ktaoua Formation (late Sandbian-early Katian). For the first time, members of the class Soluta are formally described from Morocco and Africa. All solutans from the Lower Ktaoua Formation are identified as Dendrocystites aff. sedgwicki. Three size-related morphotypes, probably corresponding to successive growth stages ('juvenile', 'adult' and 'gerontic'), could be distinguished within the abundant and well-preserved material from Morocco. The occurrence of the genus Dendrocystites in the western Tafilalt confirms the strong faunal affinities between Morocco and other regions of the Mediterranean Province (Czech Republic and Spain) in Late Ordovician times. In high palaeolatitude (peri-)Gondwanan areas, Dendrocystites was a gregarious solutan living in shallow, siliciclastic settings at or above storm-wave base.

Keywords: Echinoderm Lagerstätte, Soluta, Upper Ordovician, Morocco 
In the last 15 years, several spectacular echinoderm Lagerstätten (also informally designated 'starfish beds', even when starfish are absent) were discovered and exploited for commercial purposes in Upper Ordovician sandstones of the eastern Anti-Atlas (western Tafilalt), Morocco (Lefebvre et al. 2010; Lebrun 2018; Gutiérrez-Marco et al. 2020; Gutiérrez-Marco \& García-Bellido this volume). These localities have yielded abundant, fully articulated echinoderms with their finest morphological details preserved, such as complete blastozoan feeding appendages (brachioles) or delicate pinnules on crinoid arms (see e.g. Lefebvre et al. 2007, 2008, this volume; Hunter et al. 2010; Nardin \& Régnault 2015; Botting this volume; Zamora et al. this volume). The discovery of these numerous starfish beds dramatically altered previous estimates of echinoderm diversity and palaeocology in the Upper Ordovician of the western Tafilalt area. All previous studies on Late Ordovician echinoderms from the eastern Anti-Atlas had described moderately diverse assemblages dominated by diploporite blastozoans (mostly aristocystitids and sphaeronitids) and associated with moderately deep (shelf) environmental conditions (Chauvel 1966, 1977, 1978; Termier \& Termier 1970; Lefebvre \& Fatka 2003; Álvaro et al. 2007). The Tafilalt starfish beds yielded markedly different associations dominated by other echinoderm groups (e.g. asterozoans, eocrinoids, solutans, stylophorans) and corresponding to the sudden burial of in-situ or, more often, downslope transported dense populations of echinoderms originally living in shallow settings (Lefebvre et al. 2007, 2008, 2010, this volume; Nardin 2007; Régnault 2007; Hunter et al. 2010; Nardin \& Régnault 2015; Botting this volume; Zamora et al. this volume). Although echinoderms usually occur as mass occurrences with little or no associated fauna, other levels within the Upper Ordovician of the western Tafilalt have also provided abundant and diverse remains of many other invertebrates, such as brachiopods (Havlíček 1971; Colmenar et al. this volume; Villas \& Colmenar this volume), bryozoans (Destombes et al. 1971; Ernst this volume), conulariids (Van Iten et al. this volume), molluscs (Babin \& Destombes 1990; 
Horný 1997; Ebbestad et al. this volume), and trilobites (Destombes 1972; Gutiérrez-Marco et al. $a$ this volume). Some localities have also yielded exquisitely preserved lightly sclerotized arthropods (e.g. cheloniellids; Van Roy 2006), paropsonemid eldonioids (Van Roy 2006; MacGabhann 2012), hydroids (Gutiérrez-Marco et al. $b$ this volume), machaeridian annelids (Vinther et al. 2008) and palaeoscolecid worms (Gutiérrez-Marco \& García-Bellido 2015).

This study focuses on the locally abundant, well-preserved material of solutans occurring in the Lower Ktaoua Formation (Sandbian-early Katian) of the Tafilalt area. Solutans are a small clade of non-radiate blastozoan echinoderms ranging from the middle Cambrian (Drumian) to the Lower Devonian (Emsian) (Dehm 1934; Caster 1968; Ubaghs \& Robison 1988; Daley 1996; Parsley 1997; Domínguez et al. 2002; Rahman \& Lintz 2012; Noailles et al. 2014). The class probably originated in Laurentia (Drumian-Guzhangian; Ubaghs \& Robison 1985, 1988; Daley 1995, 1996; Lefebvre \& Lerosey-Aubril 2018) before spreading to peri-Gondwanan areas in the Furongian (South China; Zamora et al. 2013b; Zhu et al. 2016) and the Lower Ordovician (France, Morocco; Thoral 1935; Ubaghs 1969; Lefebvre et al. 2016). In Middle Ordovician times, the fossil record of solutans is restricted to periGondwanan areas (e.g. Bohemia; Prokop \& Petr 2003; Lefebvre et al. 2012) and Avalonia (Lefebvre et al. 2012). Solutan diversity and palaeobiogeographic distribution both peaked in Late Ordovician times with abundant remains described in Baltica (Rozhnov \& Jefferies 1996), several peri-Gondwanan areas (Barrande 1887; Gil Cid et al. 1996; Lefebvre et al. 2007, 2010; Hunter et al. 2010; Noailles et al. 2014), and mostly in Laurentia, where this class underwent a major diversification (Bather 1913; Parsley \& Caster 1965; Parsley 1972; Kolata 1973; Kolata et al. 1977; Jefferies 1990; Daley 1992). No solutan taxa have been described so far from Silurian strata, suggesting that this class was very likely severely impacted by the Hirnantian mass-extinction (Domínguez et al. 2002). However, yet undescribed solutan remains have been found in the Silurian - Wenlock of Wales (B. 
97

Lefebvre, pers. obs., 2008), and several occurrences of this class were described in the Lower Devonian of Australia (Gill \& Caster 1960), Germany (Dehm 1934; Rahman \& Lintz 2012) and North America (Parsley \& Sumrall 2007). This macroevolutionary pattern with two distinct peaks in diversity in the Upper Ordovician and the Lower Devonian separated by a Silurian gap is not unique to solutans, but is also observed in other groups of flattened, asymmetrical and unattached echinoderms (e.g. pleurocystitid rhombiferans, mitrate stylophorans; see e.g. Lefebvre 2007a; Parsley \& Sumrall 2007).

Although solutans have been regularly mentioned as the dominant faunal element of several Moroccan echinoderm dense beds in the Lower Ordovician of the Central Anti-Atlas (see e.g. Lefebvre \& Fatka 2003; Lefebvre 2007a; Lefebvre et al. 2016) and the Upper Ordovician of the western Tafilalt (see e.g. Lefebvre et al. 2007, 2008; Hunter et al. 2010), their taxonomy and palaeoecology have never been investigated so far. Consequently, this preliminary study aims at partly filling this gap in knowledge, by providing the first taxonomic description of Late Ordovician solutans from Morocco and from Africa, as well as the first detailed discussion of their palaeoecology, taphonomy and palaeobiogeographic affinities. Contrary to the Fezouata Shale (Tremadocian-Floian), which has yielded a relatively diverse solutan remains belonging to at least three distinct genera (Castericystis?, Minervaecystis and Plasiacystis; Lefebvre et al. 2016), all solutans found so far in the Lower Ktaoua Formation belong to one single genus (Dendrocystites).

8

\section{Geological setting and stratigraphy}

The study material was collected from eight distinct localities, all situated within the western Tafilalt area, eastern Anti-Atlas (Morocco). Seven of these sites occur within a narrow and elongate area (about $3 \mathrm{~km}$ wide and $25 \mathrm{~km}$ long), orientated about N10 road, extending from 
the western flank of Jbel Tijarfaïouine (to the North) to Isthlou and Jbel Signit (to the South), on both sides of the N12 road between Msissi (about $25 \mathrm{~km}$ to the West) and Rissani (about $30 \mathrm{~km}$ to the East) (see Fig. 1). The other locality (Jbel Taklimt) is situated slightly eastwards, about $4 \mathrm{~km}$ south of the N12 road and $16 \mathrm{~km} \mathrm{~W}$ of Rissani (Fig. 1).

The stratigraphic position of each locality was difficult to identify precisely, due to the rarity or even lack of associated faunal elements useful for stratigraphic purposes (e.g. brachiopods, graptolites, trilobites) within echinoderm dense beds, and also because of the widespread occurrence of homogeneous, sandstone-dominated lithologies throughout most of the Upper Ordovician succession in this area (Destombes 2006a, $b$; Álvaro et al. this volume). In spite of these difficulties and pending a detailed sedimentological and stratigraphic reevaluation of the Upper Ordovician in this area is performed, the stratigraphic positions of solutan localities could be evaluated based on field observations made with J. Destombes, while visiting most of these sites (Oct. 2010), and also through the careful report of their GPS coordinates on the two corresponding 1:200.000 geological maps of Tafilalt-Taouz (Service géologique du Maroc 1986) and Todrha-Maïder (Service géologique du Maroc 1988). In the western Tafilalt area, solutan occurrences can be assigned to four successive stratigraphic intervals, all situated within the Lower Ktaoua Formation (Fig. 2).

The Piste de Jorf locality (ECR-F3; Fig. 1b) corresponds to a long and deep trench quarried within sandstones identified as 'Or5a' (lower part of the Lower Ktaoua Formation; Fig. 2) on the 1:200.000 geological map (Todrha-Maïder; Service géologique du Maroc 1988), along the banks of a dried oued. This site was exploited by local fossil dealers to extract large slabs of sandstones covered with particularly abundant, fully articulated specimens of ophiuroids and paranacystid mitrates (Lefebvre et al. 2007, 2010; Hunter et al. 2010). Other faunal elements are particularly rare and comprise eocrinoids (Cardiocystites; Nardin 2007) and the oldest 
solutans documented so far in the Upper Ordovician of the eastern Anti-Atlas (Lefebvre et al. 2007, 2010; Noailles-Gobry 2008; Hunter et al. 2010; Lebrun 2018).

Jbel Taklimt (ECR-F9; Fig. 1b) is a classical section for the Upper Ordovician succession in the western Tafilalt area (see Destombes 2006b). Solutans were sampled on sandstone slabs in the middle part of the Lower Ktaoua Formation (Fig. 2), around the boundary between units mapped as 'Or5a' and 'Or5b' on the 1:200.000 geological map (Tafilalt-Taouz; Service géologique du Maroc 1986). In ECR-F9, fully articulated solutans are locally abundant, densely packed and current-oriented. Other faunal elements include brachiopods, ophiuroids, trilobites, as well as large conulariids encrusted by numerous edrioasteroids. About $20 \mathrm{~km}$ SW of Jbel Taklimt, two other localities (ECR-F12 and ECR-F13; Fig. 1b), both located on the western flank of Jbel Signit, have yielded abundant and well-preserved assemblages from the same stratigraphic interval as ECR-F9 (middle part of the Lower Ktaoua Formation; Fig. 2). In both ECR-F12 and ECR-F13, solutans are a minor component of a diverse invertebrate fauna comprising asterozoans (asteroids and ophiuroids), brachiopods, bryozoans, crinoids, glyptocystitids (Homocystites), fully articulated machaeridian annelids (Plumulites), mitrate stylophorans (kirkocystids, mitrocystitids), and trilobites.

In Tizi n'Mourghi ('the cricket's pass', ECR-F1; Fig. 1b), two main fossiliferous intervals have been intensively quarried by local fossil traders to extract large slabs of sandstones with ophiuroids and/or solutans (Lebrun 2018). This hill is the only locality in the western Tafilalt area, which yielded low-diversity, solutan-dominated assemblages. These solutan dense beds occur in the upper part of the section, in sandstones mapped as 'Or5b' (upper part of the Lower Ktaoua Formation; Fig. 2) on 1:200.000 geological maps (Service géologique du Maroc 1986, 1988). Other faunal elements are particularly rare and consist almost exclusively of other echinoderms: crinoids, diploporites (Asterocystis), glyptocystitids (Homocystites), ophiuroids, and stylophorans (mitrocystitid mitrates) (Lefebvre et al. 2007, 2010; Hunter et al. 2010; 
Zamora et al. this volume). In the upper part of the Tizi n'Mourghi section, solutans are fully articulated, more or less densely packed and generally current-oriented (Noailles-Gobry 2008). Lower in the section, solutans are also present, but they are isolated and represent minor elements of an ophiuroid-dominated assemblage. About $5 \mathrm{~km} \mathrm{SW}$ of ECR-F1, rare solutan specimens were collected near the dried river Oued El Caïd Rami (ECR-F7; Fig. 1b), in sandstones from the same stratigraphic interval (upper part of the Lower Ktaoua Formation). This locality yielded a moderately diverse assemblage comprising glyptocystitid rhombiferans (Homocystites), ophiuroids and trilobites. Rare, fully articulated solutans were also found at locality ECR-F19 (Jbel Signit; Fig. 1b), within sandstones mapped as 'Or5b' (upper part of the Lower Ktaoua Formation; Fig. 2) on the 1:200.000 geological map of Todrha-Maïder (Service géologique du Maroc 1988). These levels provided a well-preserved, relatively diverse invertebrate fauna comprising asterozoans, crinoids, edrioasteroids, and machaeridians (Plumulites).

Few, well-preserved specimens of the youngest known Moroccan solutans were found at Isthlou (ECR-F6; Fig. 1b), in the uppermost levels of the Lower Ktaoua Formation (Fig. 2), i.e. immediately below the contact with the overlying Upper Tiouririne Formation (Or5bOr5c boundary on the 1:200.000 Todrha-Maïder geological map; Service géologique du Maroc 1988). No solutan remains were found in the particularly fossiliferous overlying levels of the Upper Tiouririne Formation, in which abundant and diverse echinoderms (asteroids, crinoids, diploporites, edrioasteroids, ophiuroids, rhombiferans, mitrate stylophorans) occur along with brachiopods, bryozoans, conulariids (Pseudoconularia), and various trilobites (e.g. illaenids, trinucleids) (see e.g. Lebrun 2018; Botting this volume; Sumrall \& Zamora this volume).

\section{Material and methods}


178 Over 100 individuals of Dendrocystites were collected from eight distinct localities (see above; Fig. 1). All of them are preserved as natural moulds in sandstones. Most specimens are complete and fully articulated, with their homoiostele and/or brachiole still attached to the theca (Figs 3-6). Specimens were casted with latex, so as to reveal their original, threedimensional morphology. Latex casts were then whitened with ammonium chloride $\left(\mathrm{NH}_{4} \mathrm{Cl}\right)$ and photographed with a Canon EOS 70 D digital camera. Graphic work was done using the software Corel Draw X8 and GIMP 2.10.8. Classical morphological measurements (thecal height $\mathrm{TH}$, brachiole length $\mathrm{BL}$, and homoiostele length $\mathrm{HL}$ ) were made with the software Image J on a selection of the thirty best preserved and most complete individuals.

Institutional abbreviations. Specimens used in this study are housed in the following public scientific collections: Université Cadi-Ayyad, Marrakesh, Morocco (AA); Muséum d'Histoire Naturelle, Marseille, France (MHNM); Muséum d'Histoire Naturelle de Nantes, France

(MHNN); Muséum d'Histoire Naturelle, Toulouse, France (MHNT); Musée des Confluences, Lyon, France (ML); and Collections de Paléontologie, Université Lyon 1, Villeurbanne, France (UCBL.FSL).

\section{Systematic palaeontology}

Solutans are considered herein as a distinct class of blastozoan echinoderms characterized by the possession of a single free ambulacral structure (brachiole) and a longitudinally differentiated stem-like appendage (homoiostele) (David et al. 2000; Sprinkle \& Guensburg 2004; Nardin et al. 2009; Lefebvre et al. 2013; Noailles et al. 2014; for alternative 
interpretations see e.g. Jefferies 1990; Smith 2005). Solutan systematics and morphological terminology are following Noailles et al. (2014).

Phylum Echinodermata Bruguière, 1791 (ex Klein, 1734)

Subphylum Blastozoa Sprinkle, 1973

Class Soluta Jaekel, 1901

Order Dendrocystitida Noailles, Lefebvre \& Kašička, 2014

Family Dendrocystitidae Bassler, 1938

Genus Dendrocystites Barrande, 1887

Type species. Cystidea sedgwicki Barrande, 1867 from the Upper Ordovician of the Barrandian area, Czech Republic.

Remarks. All Late Ordovician Moroccan solutans can be unambiguously assigned to the order Dendrocystitida, based on the narrow, elongate and cylindrical morphology of their dististele, which clearly departs from the morphology found in Coleicarpus (longitudinally undifferentiated holdfast) and syringocrinids (with a flattened and enlarged dististele). Within dendrocystitids, the Tafilalt material can be affiliated to the family Dendrocystitidae, and specifically to the genus Dendrocystites, based on its cordiform to pear-shaped thecal outlines, the presence of a large anal lobe containing a single 'sugar-loaf' skeletal element, and the absence of any antibrachial lobe.

\footnotetext{
2007b Dendrocystites sp. - Lefebvre, p. 243, fig. 1.3
} 
2007 Dendrocystites sp. - Lefebvre et al., p. 130, table 2

2008 Dendrocystites sedgwicki (Barrande) - Noailles-Gobry, p. 15, fig. 8, pl. 1,3,4

2008 solute indet., gen. et sp. nov. - Noailles-Gobry, p. 17, pl. 2

2010 Dendrocystites sp. - Hunter et al., p. 25, figs 4,5

2010 Dendrocystites-like solute - Hunter et al., p. 25

2010 Dendrocystites sedgwicki (Barrande) - Lefebvre et al., p. 9, fig. 7A

2010 solute indet. - Lefebvre et al., p. 8, fig. 6A

2014 Dendrocystites sedgwicki (Barrande) - Noailles et al., p. 466

2018 Dendrocystites sp. - Lebrun, p. 129, fig. C

2018 Dendrocystites sedgwicki (Barrande) - Lebrun, p. 129, fig. E

Material. The study material of Dendrocystites aff. sedgwicki comprises 87 registered specimens (some of them preserving several individuals) collected in eight distinct localities, all from the Lower Ktaoua Formation (late Sandbian-early Katian) of the western Tafilalt area, eastern Anti-Atlas, Morocco (see above; Figs 1-2). Most specimens (67) are from ECRF1, Tizi n'Mourghi (Ka2, early Katian): AA.TNMa.OS.1 (coll. Lefebvre); AA.TNMb.OS.1-5, 10-12, 16-17, 19-21, 23, 30-31 (coll. Lefebvre); AA.TNMc.OS.1 (coll. Lefebvre); UCBL.FSL.712888-712889 (coll. Reboul); MHNM.15406.1, 10, 15, 19, 33 (coll. Reboul); MHNM.15690.111 (coll. Reboul); MHNT.PAL.2005.0.138, 150-151 (coll. Reboul); ML20.269416, 269419-269432, 269434-259456 (coll. Reboul). Five specimens were collected in ECR-F3, Piste de Jorf (Sa2, late Katian): AA.PDJ.OS.4 (coll. Lefebvre); MHNM.15406.2, 13 (coll. Reboul); MHNN.P.045601, 045611 (coll. Reboul). Three specimens are from ECR-F6, Isthlou (Ka2, early Katian): AA.IST.OS.13 (coll. Lefebvre); UCBL.FSL.711732, 711739 (coll. Reboul). Two specimens were found in ECR-F7, Oued El Caïd Rami (Ka2, early Katian): AA.OCR.OS.15-16 (coll. Lefebvre). One specimen on a slab 
was collected in ECR-F9, Jbel Taklimt (Ka1, early Katian): AA.JTK.OS.1 (coll. Lefebvre). Six specimens are from ECR-F12, Tarafin Signit (Ka1, early Katian): UCBL.FSL.712080, 712858 (coll. Reboul); UCBL.FSL.712911, 713028-29, 713053 (coll. Auvray). Two specimens were collected in ECR-F13, Tarafin (Ka1, early Katian): UCBL.FSL.712068 (coll. Reboul); UCBL.FSL.713037 (coll. Auvray). The last specimen was found in ECR-19, Kraouia (Ka2, early Katian): UCBL.FSL.712832 (coll. Reboul).

Occurrence. Lower Ktaoua Formation (late Sandbian-early Katian), Tafilalt area, eastern Anti-Atlas (Morocco) (see above; Fig. 2).

Description. Theca flattened, asymmetrical, generally cordiform (Fig. 5) or pear-shaped, with well-defined pre-anal lobe (see Fig. 6), rarely with more rounded outlines and no distinct preanal lobe (e.g. MHNN.P.045601; see Fig. 4a). Theca made of numerous polygonal plates (around 50 in smallest individuals, over 100 in large ones), forming tessellate, unorganized pavement displaying typical rosetting pattern, with large skeletal elements separated by smaller, intercalated ones (Fig. 5-6). Thecal plates smooth, without any ornamentation (knobs, ridges), even in largest observed specimens (Fig. 6). Thecal height (TH) ranging from $10 \mathrm{~mm}$ in smallest individuals (Fig. 3) to almost $40 \mathrm{~mm}$ in largest one (MHNM.15406.1) with mean estimated value around $21 \mathrm{~mm}$. Anal opening covered by single, large sugar-loaf plate (Fig. 5c). Hydropore at summit of small tubercle (e.g. ML20.269419), next to brachiole insertion. Gonopore not observed. Brachiole and homoiostele inserted sharply, at opposite ends of theca.

Single, distally tapering, uni- or biserial brachiole inserted in apical position. Brachiole length variable, ranging from 7.4 to $23.9 \mathrm{~mm}$ (estimated mean value: $11.8 \mathrm{~mm}$ ), often longer 
275 than thecal height in small individuals (Fig. 3a), shorter than TH, in larger specimens (Fig. 5c, $2766 a, c, e)$.

277 Homoiostele, elongate, distally tapering, hollow, multimeric stem-like structure 278 longitudinally differentiated into proxistele and dististele. Proxistele shorter and wider than 279 dististele. Proxistele consisting of distinct, telescopic tetrameric rings in variable number, generally six to eight in medium-sized specimens (Fig. 5). In large individuals, proximal rings more numerous, with abundant, small scale-like integumentary platelets intercalated in

282

between them (Fig. 6). Dististele made of two longitudinal rows (upper and lower series) of quadrangular plates (Fig. 4-6). No complete homoiostele preserved (distal tips always missing), but HL consistently longer than $\mathrm{TH}$, and varying from 10 to almost $100 \mathrm{~mm}$ (mean estimated value for HL: $36.4 \mathrm{~mm}$ ). No attachment structure or distal hook observed in available material.

Ontogeny. Three main size-related morphotypes can be identified within the specimens of Moroccan Dendrocystites, based on differences in proxistele organization and in thecal height, plating and outlines. As all three morphotypes occur together at the same localities (when sample size is large enough) and can be observed throughout the succession from the stratigraphically lowest (e.g. ECR-F3) to the stratigraphically highest occurrences (e.g. ECRF6) in the Lower Ktaoua Formation, it is very likely that they correspond to successive ontogenetic stages of one single species. Ontogenetic development is a continual process without strict boundaries between the different, successive growth stages. However, terms such as 'juvenile', 'adult', and 'gerontic' have been widely used in the literature to informally describe size-related morphotypes (small, medium-sized, and large, respectively) observed in various blastozoans (e.g. eocrinoids, rhombiferans) (see e.g. Parsley 2009, 2012; Zamora et al. 2013a, this volume; Nohejlová \& Fatka 2016). 
The 'juvenile morphotype' (Fig. 4) can be observed in two individuals from ECR-F1 and two others from ECR-F3, all characterized by the particularly small size of their theca $(\mathrm{TH} \approx$ $10 \mathrm{~mm}$ ) compared to other specimens of Moroccan Dendrocystites. These four 'juvenile' individuals are lacking a well-developed pre-anal lobe. Consequently, their thecal outlines are regularly convex, almost rounded (MHNN.P.045601; Fig. 4a) to cordiform (Fig. 4b, c). Their thecal plates are few in number (around 50), smooth and all more or less of the same size. Their proxistele consists of few, well-organized tetramerous rings with no intercalated platelets. These four Moroccan individuals are morphologically very similar to small-sized, juvenile specimens of Dendocystites barrandei Bather, 1913 from the Barrandian area of the Czech Republic (see Noailles et al. 2014, fig. 9B).

The medium-sized 'adult morphotype' (Fig. 5) is more widely distributed (about 40 percent of study material) within most Moroccan assemblages (e.g. ECR-F1, ECR-F6, ECR-F7, ECRF9, ECR-F12). Specimens are characterized by a relatively large cordiform theca $(10 \mathrm{~mm}<$ $\mathrm{TH}<20 \mathrm{~mm}$ ) made of numerous, smooth skeletal elements (around 100) of unequal sizes. Their proxistele is made of several rings with few intercalated platelets. These Moroccan individuals of Dendrocystites look very similar to the largest observed specimens of $D$. barrandei and also to medium-sized individuals of D. sedgwicki from the Barrandian area, Czech Republic (see Noailles et al. 2014, fig. 5).

The large 'gerontic morphotype' (Fig. 6) is the most frequently observed within the Moroccan material and it occurs from the base to the top of the Lower Ktaoua Formation (e.g. in ECR-F1, ECR-F3, ECR-F6, ECR-F7, ECR-F13). It corresponds to large-sized individuals (TH $>20 \mathrm{~mm}$ ), with a pear-shaped theca and a prominent, well-distinct pre-anal lobe. Thecal plates are numerous, strongly unequal in size, and consistently smooth. The proxistele is made of unorganized rings, largely separated from each other by extremely abundant small, scalelike platelets (Fig. 6b). The Moroccan 'gerontic morphotype' shares several similarities with 
the morphology of the largest specimens of Dendrocystites sedgwicki from the Barrandian area, Czech Republic (see Noailles et al. 2014, fig.6): comparable thecal pear-shaped outlines, largely developed pre-anal lobe, several generations of thecal plates, largely unorganized proxistele with abundant platelets. However, all 'gerontic' specimens from Morocco lack the typical thecal ornamentation occurring in large individuals of D. sedgwicki, consisting of fine ridges radiating from a central knob (see Barrande 1887; Bather 1913; Caster 1968; Noailles et al. 2014).

Discusion. The Moroccan material of Dendrocystites is morphologically close to the two Bohemian solutans Dendocystites barrandei from the Letná Formation (late Sandbian) and $D$. sedgwicki from the Záhořany Formation (early Katian). The two Czech taxa differ in proxistele organization, as well as in thecal size, outlines, ornamentation and plating (see Bather 1913; Caster 1968; Noailles-Gobry 2008; Noailles et al. 2014). In the largest known specimens of $D$. barrandei, TH is about one third smaller than in the largest individuals of $D$. sedgwicki (Noailles et al. 2014). Thecal outlines are cordiform in D. barrandei, but more asymmetrical and pear-shaped in $D$. sedgwicki, because of the more prominent pre-anal lobe (Bather 1913; Caster 1968; Noailles et al. 2014). The theca of D. barrandei is made of few, relatively large skeletal elements, whereas $D$. sedgwicki has usually more thecal plates, including small 'secondary' platelets intercalated between larger 'primary' ones ('rosetting pattern'; Noailles et al. 2014). Moreover, all thecal plates are smooth in D. barrandei, whereas they typically display a central knob with radiating ridges in the largest individuals of $D$. sedgwicki (Bather 1913; Caster 1968; Noailles et al. 2014). Finally, the proxistele of D. barrandei consists of distinct, tetramerous rings with few integumentary platelets, whereas in large specimens of D. sedgwicki, rings are more discontinuous and separated by abundant small scale-like elements (Bather 1913; Caster 1968; Noailles et al. 2014). The two taxa have 
also a distinct stratigraphic distribution, with $D$. barrandei occurring in older levels than $D$. sedgwicki (Bather 1913; Caster 1968). However, the D. barrandei-like morphology of small and medium-sized specimens of D. sedgwicki lead Noailles et al. (2014) to suggest that the characteristic features observed in the largest specimens of D. sedgwicki were possibly hyperadult characters and the result of heterochronic processes (hypermorphosis).

The situation is different in Morocco, where no obvious morphological transition can be observed between the successive assemblages of Dendrocystites, although their relatively long stratigraphic range (late Sanbian-early Katian; Fig. 2) is equivalent to that of both $D$. barrandei and D. sedgwicki in the Barrandian area. Contrary to the situation in Bohemia, where only two morphotypes ('juvenile' and 'adult') are originally occurring in the late Sandbian (Letná Formation; D. barrandei), and the third one ('gerontic') appears later in the early Katian (Záhořany Formation; D. sedgwicki), all three morphotypes are continuously present during the same stratigraphic interval in Morocco. Although small and medium-sized solutans from the Tafilalt area are morphologically very similar to D. barrandei, Moroccan Dendrocystites cannot be assigned to that species, because of the existence of a large-sized 'gerontic' morphotype, with a lobate, pear-shaped theca and an unorganized proxistele. Similarly, in spite of numerous morphological similarities with D. sedgwicki, the Tafilalt dendrocystitids cannot be affiliated to this species, because they lack the highly distinctive ornamentation on thecal plates of 'gerontic' individuals. The Moroccan material is thus identified here as Dendrocystites aff. sedgwicki to stress that, although morphologically close to $D$. sedgwicki (e.g. 'gerontic' morphotype), it also retains features characteristic of $D$. barrandei (e.g. smooth, unornamented thecal plates). Consequently, hyperadult, 'gerontic' morphologies were acquired earlier in Morocco (late Sandbian) than in Bohemia (early Katian). It is possible that Moroccan solutans represent an ecophenotypic variation of $D$. sedgwicki: observed differences in the strength of thecal ornamentation would then simply 
result from distinct environmental conditions. It is also possible that $D$. aff. sedgwicki corresponds to a transitional evolutionary stage between $D$. barrandei and D. sedgwicki. This hypothesis could be tested, if 'intermediate', D. aff. sedgwicki-like morphologies were recovered in the Vinice Formation of Bohemia, i.e. in between the Letná and the Záhořany formations.

\section{Palaeobiogeography, taphonomy and palaeoecology}

All known occurrences of the genus Dendrocystites are restricted to a relatively narrow time interval (late Sandbian-early Katian) and a small set of (peri-)Gondwanan areas, all situated within the Mediterranean Province, i.e. at high palaeolatitudes in the southern hemisphere (Lefebvre et al. 2013). Dendrocystites barrandei is known from the Letná Formation (late Sandbian), Barrandian area, Czech Republic (Bather 1913; Caster 1968; Noailles et al. 2014) and the Cantera Shale (latest Sandbian-earliest Katian), Central Iberian Zone, Spain (Gil Cid et al. 1996; Gutiérrez-Marco et al. 2018). Yet undescribed solutan remains from the Vinice Formation (latest Sandbian-earliest Katian) possibly represent the youngest occurrence of $D$. barrandei in Bohemia (Noailles et al. 2014). Dendrocystites aff. sedgwicki occurs in several stratigraphic intervals (late Sandbian-early Katian) within the lower Ktaoua Formation, in the western Tafilalt, Morocco (Lefebvre et al., 2007, 2010; Noailles-Gobry 2008; Hunter et al. 2010; Lebrun 2018). Finally, D. sedgwicki was described from the Záhořany Formation (early Katian), Prague Basin, Czech Republic (Barrande 1887; Bather 1913; Caster 1968; Noailles et al. 2014). Yet undescribed dendrocystitids from the overlying Bohdalec Formation (early Katian) could represent the youngest occurrence of D. sedgwicki in the Barrandian area (Noailles et al. 2014). 
The occurrence of Dendrocystites in Czech Republic, Morocco and Spain supports the existence of strong faunal affinities between Late Ordovician echinoderm assemblages from these three regions (see e.g. Lefebvre 2007b; Lefebvre et al. 2007, 2013, this volume; Nardin 2007; Zamora \& Sumrall this volume; Zamora et al. this volume). The absence of Dendrocystites in other regions of the Mediterranean Province yielding otherwise very similar Late Ordovician faunas (e.g. France, Portugal) could be a result of sampling bias and/or variations in environmental conditions. Dendrocystites represents the single known dendrocystitid genus documented so far in the Upper Ordovician of (peri-)Gondwanan regions. Elsewhere, Late Ordovician dendrocystitids are taxonomically diverse and palaeogeographically widespread with occurrences in Avalonia (e.g. Girvanicystis casteri; Daley 1992), Baltica (e.g. Heckericystis kuckersiana, Maennilia estonica; Gill \& Caster 1960; Caster 1968; Rozhnov \& Jefferies 1996; Parsley et al. 2012) and Laurentia (e.g. Dendrocystoides scoticus, Girvanicystis batheri; Bather 1913; Caster 1968; Jefferies 1990; Daley 1992; Jefferies \& Daley 1996). It is thought that this Late Ordovician peak in dendrocystitid diversity and palaeobiogeographic distribution is partly a result of their expansion onto Laurentian shores, although this could also be a result of an extremely poor fossil record in older strata (Lefebvre et al. 2013). For example, 'Dendrocystites' rossicus is only species of dendrocystitid described so far in the Darriwilian (Bather 1913; Rozhnov \& Jefferies, 1996). However, an as yet undescribed solutan remains from the Hope Shale of Shropshire, England, UK (B. Lefebvre, pers. obs.) and the Šarka Formation of the Prague Basin, Czech Republic (Lefebvre et al. 2012) suggest that, in Darriwilian times, dendrocystitids were already diverse and more widely distributed palaeogeographically than previously expected (i.e. in Avalonia, Baltica and high-latitude peri-Gondwanan regions).

In the taphonomic classification of echinoderms proposed by Brett et al. (1997), solutans belong to type 1 forms, i.e. taxa with a delicate endoskeleton made of weakly sutured plates. 
Decay experiments made on Recent type 1 echinoderms (e.g. ophiuroids) suggest that, within days or a few weeks after death, their endoskeleton is totally disarticulated into isolated plates (Meyer 1971; Kerr \& Twitchett 2004). Consequently, the preservation of fully articulated, complete specimens of Dendrocystites in the Upper Ordovician of the western Tafilalt area requires their rapid burial by obrution (e.g. storm-generated, turbiditic) deposits. In several localities, and in particular in Tizi n'Mourghi (ECR-F1), where most specimens were found, solutans are densely packed, and pressed against each other, and frequently aligned in the same direction (Fig. 3). This unidirectional preservation, which is also observed in other Moroccan starfish beds (see Nardin \& Régnault 2015; Zamora et al. this volume), suggests that solutans were most likely transported a short distance by unidirectional, laminar bottom currents, before their definitive burial (Lefebvre et al. 2008, 2010; Hunter et al. 2010).

In the eastern Anti-Atlas, Late Ordovician echinoderm Lagerstätten (including most of those yielding Dendrocystites) are restricted to a relatively narrow area, more or less N-S oriented and straddling the western Tafilalt over several tens of kilometers. This trend matches very closely the distribution of conglomerates and slumps, located along a distensive fault system structured and active during the Sandbian-Katian time interval in this area (see e.g. Destombes 2006b; El Maazouz \& Hamoumi 2007). Additional biostratinomic and sedimentological investigations are necessary to determine if the Tafilalt echinoderm Lagerstätten result from the burial of para-autochthonous communities by storm deposits or from the downslope transport of shallow assemblages by turbiditic flows. Taphonomic experiments demonstrate that living or freshly killed type 1 echinoderms can endure severe hydrodynamic conditions (e.g. turbidites) with no disarticulation (Kerr \& Twitchett 2004; Gorzelak \& Salamon 2013). The Lady Burn Starfish Beds (South Thraive Formation) in the Upper Ordovician of Scotland is a well-known example of turbidite-generated echinoderm Lagerstätte (see e.g. Harper 1982; Jefferies 1990). Although they were transported downslope 
by gravity currents, thousands of complete, fully-articulated type 1 echinoderms, including abundant specimens of the two solutans Dendrocystoides scoticus and Girvanicystis batheri were collected in this starfish bed (Bather 1913; Jefferies 1990; Daley 1992; Jefferies \& Daley 1996).

Regardless whether they were buried in-situ by storm deposits or transported downslope by turbidites, Late Ordovician Moroccan solutans were originally living in shallow environmental conditions at or above storm wave base. The high density of individuals on some slabs suggests a very likely gregarious mode of life, in low-diversity echinoderm dense beds (Lefebvre et al. 2007, 2010; Hunter et al. 2010). In the western Tafilalt, solutans are frequently found associated with ophiuroids, glyptocystitid rhombiferans (e.g. Homocystites), stylophorans, and sometimes, with crinoids and edrioasteroids. In the Upper Ordovician of Bohemia and the Central Iberian Zone, Dendrocystites occurs in shallow environmental conditions and associated with echinoderm faunal elements both very similar to those documented in the western Tafilalt area. For example, the recently discovered Chrustenice echinoderm Lagerstätte (Sandbian, Letná Formation) yielded slabs covered by abundant, densely packed, current-oriented, fully articulated specimens of Dendrocystites (Fig. 7), associated with crinoids, edrioasteroids, ophiuroids, glyptocystitid rhombiferans (Homocystites) and stylophorans (Nohejlová et al. 2019). Similarly, Dendrocystites was collected at Viso del Marquès (southern Central Iberian Zone) in shallow, storm-generated, fine black shales with intraformational pebbles of the Cantera Shale, associated with crinoids, glyptocystitid rhombiferans (Homocystites) and stylophorans (Gil Cid et al. 1996; GutiérrezMarco et al. 2018; Lefebvre et al. this volume). Consequently, all known occurrences of Dendrocytites are restricted to relatively shallow, storm-influenced environmental settings.

The life orientation of solutans is still disputed and it has major implications for their mode of life (see e.g. Rahman \& Lintz 2012; Noailles et al. 2014). If solutans were living with their 
ambulacral groove facing away from the substrate (stylophoran-like orientation; see Lefebvre et al. 2019), then this would support a suspension-feeding mode of life (Bather 1913; Gill \& Caster 1960; Parsley 1972; Parsley et al. 2012; Rahman \& Lintz 2012). In contrast, if their ambulacral food groove was directed towards the substrate (pleurocystitid-like orientation; see Sumrall 2000), then solutans were very likely detritus-feeders (see e.g. Kolata 1973; Jefferies 1990; Daley 1995; Lefebvre et al. 2012; Noailles et al. 2014). Although, both life orientations are possible, rare examples of epibiontic echinoderms (edrioasteroids, eocrinoids) attached to solutans tend to support the view that solutans were detritus, rather than suspension-feeders (see Daley 1995; Lefebvre et al. 2012; Noailles et al. 2014). Similarly to pleurocystitid rhombiferans, solutans would then probably use their stout brachiole to sweep the substrate and feed on the organic matter concentrated on the sea floor. Nevertheless, the solutans from the Upper Ordovician of Morocco do not provide any evidence for this debate: all specimens were transported, at least a short distance, before burial, so that individuals showing both life orientations are often preserved side by side on a same slab. Moreover, no epibionts have been observed so far attached to specimens of Dendrocystites aff. sedgwicki. In the Upper Ordovician of the Prague Basin, several new, yet undescribed examples of edrioasteroids attached to the thecal surface of Dendrocystites could bring strengthens the brachiole downward orientation model (Nohejlová et al. 2019).

\section{Acknowledgements}

This paper is a contribution to the International Geoscience Programme (IGCP) Project 653 "The Onset of the Great Ordovician Biodiversification" Event and 735 "Rocks and the Rise of Ordovician Life: Filling knowledge gaps in the Early Palaeozoic Biodiversification”. The authors are particularly grateful to Roland and Véronique Reboul for field assistance and for 
donating many important specimens to public collections. This work also greatly benefited

500

501

502

503

504

505

506

507

508

509

510

511

512

513

514

515

516

517

518

519

520

521

522

523

from the field experience of Jacques Destombes, who also provided many important data (notes, maps). Francis Auvray is thanked for providing data on new fossiliferous sites and for donating several specimens of solutans to the palaeontological collections of Lyon 1 University. The authors are also thanking Ali Bachnou, El Medhi Bajedoub, Khadija El Hariri, Christian Gaillard, Ahmid Hafid and Nicolas Olivier for their help in the field (20092010). The authors thank Thomas Guensburg, James Sprinkle and Samuel Zamora for their useful and constructive comments, which greatly helped improving the quality of this manuscript. The authors are also grateful to Didier Berthet (Musée des Confluences), Pierre Dalous and Yves Laurent (NHM, Toulouse), Anne Médard and Sylvie Pichard (NHM, Marseille), Khaoula Kouraïss (Marrakesh University), Serge Régnault (NHM, Nantes), Emmanuel Robert (Lyon 1 University) for access to the material deposited in the public collections they are curating. We also wish to thank the editor Aaron W. Hunter (University of Cambridge \& The University of Western Australia) for help during field work and his patience during writing this paper.

\section{Funding}

The authors are grateful to the LABEX Lyon Institute of Origins (ANR-10-LABX-0066) of the Université de Lyon for its financial support within the program "Investissements d'Avenir" (ANR-11-IDEX-0007) of the French government operated by the National Research Agency (ANR). Field work in the Tafilalt area was funded by the CNRS-CNRST French-Moroccan cooperation project "Les faunes à conservation exceptionnelle de l'Ordovicien de l'Anti-Atlas (Maroc): implications évolutives et écologiques" (2009-2012). This paper is also supported by the Grant Agency of the Czech Republic Project No.18- 
$14575 \mathrm{~S}$ and is an outcome of the European Synthesys projects GB-TAF-4565 and CZ-TAF6049.

\section{References}

Álvaro, J.J., Vennin, E., Villas, E., Destombes, J. \& Vizcaïno, D. 2007. Pre-Hirnantian (latest Ordovician) benthic community assemblages: Controls and replacements in a silicilastic-dominated platform of the eastern Anti-Atlas, Morocco. Palaeogeography, Palaeoclimatology, Palaeoecology, 245, 20-36.

Álvaro, J.J., Benharref, M., Destombes, J., Gutiérrez-Marco, J.C., Hunter, A.W., Lefebvre, B., VAN Roy, P. \& ZAMORA, S. this volume. Ordovician stratigraphy and benthic community replacements in the eastern Anti-Atlas, Morocco. In: HunTER, A.W., Álvaro, J.J., Lefebvre, B., Van Roy, P. \& Zamora, S. (eds) The Great Ordovician Biodiversification Event: Insights from the Tafilalt Biota, Morocco. Geological Society, London, Special Publications, 485.

BABin, C. \& Destombes, J. 1990. Les mollusques bivalves et rostroconches ordoviciens de l'Anti-Atlas marocain: intérêt paléogéographique de leur inventaire. Géologie Méditerranéenne, 17(3), 243-261.

BARRANDE, J. 1887. Systême silurien du centre de la Bohême. $1^{\text {ère }}$ partie: Recherches paléontologiques. Volume 7. Classe des Echinodermes. Ordre des Cystidées. Gerhard, Leipzig \& Řivnáč, Prague, 233 p.

BAssler, R. S. 1938. Pelmatozoa Palaeozoica (Generum et Genotyporum Index et Bibliographia). Fossilium Catalogus I Animalia, 83, 1-194.

BAtHeR, F.A. 1913. Caradocian Cystidea from Girvan. Transactions of the Royal Society of Edinburgh, 49, 359-529. 
Botting, J.P. this volume. Late Ordovician crinoids from the Anti-Atlas region of Morocco. In: Hunter, A.W., Álvaro, J.J., Lefebvre, B., Van Roy, P. \& Zamora, S. (eds) The Great Ordovician Biodiversification Event: Insights from the Tafilalt Biota, Morocco. Geological Society, London, Special Publications, 485.

Brett, C.E., Moffat, H.A. \& TAYloR, W. 1997. Echinoderm taphonomy, taphofacies, and Lagerstätten. In: WATERS, J.A. \& MAPLES, C.G. (eds), Geobiology of Echinoderms. Paleontological Society Papers, 3, 147-190.

Bruguiere, J.G. 1791. Tableau Encyclopédique et Méthodique des Trois Règnes de la Nature, contenant l'Helminthologie, ou les vers Infusoires, les vers Intestins, les vers Mollusques, etc., Volume 7. 180 pp. Panckoucke, Paris.

CAster, K.E. 1968. Homoiostelea. In: MoOre, R.C. (ed.) Treatise on Invertebrate Paleontology, part S, Echinodermata 1(2). Geological Society of America,New York; University of Kansas, Lawrence, S581-S627.

Chauvel, J. 1966. Échinodermes de l'Ordovicien du Maroc. Editions du CNRS, Paris, 120 p.

Chauvel, J. 1977. Note complémentaire sur les cystoïdes rhombifères (Echinodermes) de l'Ordovicien marocain. Notes du Service géologique du Maroc, 38, 115-139.

Chauvel, J. 1978. Compléments sur les échinodermes du Paléozoïque marocain (diploporites, éocrinoïdes, édrioastéroïdés). Notes et Mémoires du Service géologique du Maroc, 272, 27-78.

Colmenar, J., Villas, E. \& Rasmussen, C.M.Ø. this volume. A synopsis of Late Ordovician brachiopod diversity in the Anti-Atlas, Morocco. In: HunTER, A.W., Álvaro, J.J., Lefebvre, B., VAn Roy, P. \& Zamora, S. (eds) The Great Ordovician Biodiversification Event: Insights from the Tafilalt Biota, Morocco. Geological Society, London, Special Publications, 485. 
574 Daley, P.E.J. 1992. The anatomy of the solute Girvanicystis batheri (?Chordata) from the 575 Upper Ordovician of Scotland and a new species of Girvanicystis from the Upper 576 Ordovician of south Wales. Zoological Journal of the Linnean Society, 105, 353-375.

DALEY, P.E.J. 1995. Anatomy, locomotion and ontogeny of the solute Castericystis vali from the Middle Cambrian of Utah. Geobios, 28, 585-615.

DALEY, P.E.J. 1996. The first solute which is attached as an adult: a Mid-Cambrian fossil from Utah with echinoderm and chordate affinities. Zoological Journal of the Linnean Society, 117, 405-440.

David, B., Lefebvre, B., Mooi, R. \& Parsley, R. 2000. Are homalozoans echinoderms? An answer from the extraxial-axial theory. Paleobiology, 26, 529-555.

DenM, R. 1934. Untersuchungen an Cystoideen des rheinischen Unterdevons. Sitzungsberichte Bayerischen Akademie der Wissenschaften, Mathematischnaturwissenschaftliche Abteilung, 1934, 19-43.

Destombes, J. 1972. Les trilobites du sous-ordre des Phacopina de l'Ordovicien de l'AntiAtlas (Maroc). Notes et Mémoires du Service géologique du Maroc, 240, 1-113.

Destombes, J. 2006a. Carte géologique au 1/200 000 de l'Anti-Atlas marocain. Notice explicative. Paléozoïque inférieur : Cambrien moyen et supérieur - Ordovicien - Base du Silurien. Feuille Todrha- Maïder. Chapitre D. Notes \& Mémoires du Service géologique du Maroc, 243bis, 1-58.

Destombes, J. 2006b. Carte géologique au 1/200 000 de l'Anti-Atlas marocain. Notice explicative. Paléozoïque inférieur : Cambrien moyen et supérieur - Ordovicien - Base du Silurien. Feuille Tafilalt - Taouz. Chapitre E. Notes $\&$ Mémoires $d u$ Service géologique du Maroc, 244bis, 1-69. 
Destombes, J., Termier, H. \& Termier, G. 1971. Sur quelques bryozoaires ectoproctes de l'Ordovicien supérieur du Sud marocain. Notes du Service géologique du Maroc, 31, 6164.

DomingueZ, P.D., JefFERIES, R.P.S. \& GIL CID, M.D. 2002. An annotated check-list of genera and species of carpoids. Coloquios de Paleontología, 53, 33-68.

Ebbestad, J.O., PolechovÁ, M., KröGer, B. \& Gutiérrez-Marco, J.C. this volume. Late Ordovician molluscs of the central and eastern Anti-Atlas, Morocco. In: HunTER, A.W., Álvaro, J.J., Lefebvre, B., Van Roy, P. \& Zamora, S. (eds) The Great Ordovician Biodiversification Event: Insights from the Tafilalt Biota, Morocco. Geological Society, London, Special Publications, 485.

El MaAzouz, B. \& Hamoumi, N. 2007. Différenciation paléogéographique à l'Ordovicien supérieur dans le Tafilalt (Anti-Atlas oriental, Maroc) sous l'interaction de la glaciation et de la tectonique. Comptes Rendus Geoscience, 339, 562-571.

ERnst, A. this volume. Upper Ordovician bryozoans of Morocco. In: HunTER, A.W., Álvaro, J.J., Lefebvre, B., Van Roy, P. \& Zamora, S. (eds) The Great Ordovician Biodiversification Event: Insights from the Tafilalt Biota, Morocco. Geological Society, London, Special Publications, 485.

Gil Cid, M.D., Domínguez Alonso, P.D., Silván Pobes, E. \& Escribano Ródenas, M. 1996. Bohemiaecystis jefferiesi n. sp.; primer Cornuta para el Ordovícico español. Estudios Geologicos, 52, 313-326.

GILl, E.D. \& CASTER, K.E. 1960. Carpoid echinoderms from the Silurian and Devonian of Australia. Bulletins of American Paleontology, 41, 1-71.

GorzelaK, P. \& SALAmon, M.A. 2013. Experimental tumbling of echinoderms Taphonomic patterns and implications. Palaeogeography, Palaeoclimatology, Palaeoecology, 386, 569-574. 
Gutiérrez-Marco, J.C. \& García-Bellido, D.C. 2015. Micrometric detail in palaeoscolecid worms from Late Ordovician sandstones of the Tafilalt KonservatLagerstätte, Morocco. Gondwana Research, 28, 875-881.

GutiÉRrez-MArCo, J.C. \& GARCÍA-BELlido, D.C. this volume. The international fossil trade from the Paleozoic of the Anti-Atlas, Morocco. In: Hunter, A.W., Álvaro, J.J., Lefebvre, B., VAn Roy, P. \& Zamora, S. (eds) The Great Ordovician Biodiversification Event: Insights from the Tafilalt Biota, Morocco. Geological Society, London, Special Publications, 485.

Gutiérrez-Marco, J.C., Pereira, S., Colmenar, J., Zamora, S. \& RÁbano, I. 2018. Middle Berounian (ca. Sandbian 2-Katian 1) trilobite, brachiopod and echinoderm assemblages from the southern Central Iberian Zone, Spain. In: The Fossil Week, Abstract Book, 5th International Palaeontological Congress, 9-13 July 2018, Paris. MNHN and Sorbonne University, Paris, 844.

Gutiérrez-Marco, J.C., Van Roy, P., Lefebvre, B., Zamora, S., Pereira, S. \& RÁbano, I. 2020. Le Tafilalt Biota: des animaux au corps mou dans des sables de l'Ordovicien supérieur du Maroc. Géochronique, 153, 45-51.

Gutiérrez-Marco, J.C., Pereira S., García-Bellido, D.C. \& RÁBano, I. this volume $a$. Ordovician trilobites from the Tafilalt Lagerstätte: new data and reappraisal of the Bou Nemrou assemblage. In: Hunter, A.W., Álvaro, J.J., Lefebvre, B., VAn Roy, P. \& ZAMORA, S. (eds) The Great Ordovician Biodiversification Event: Insights from the Tafilalt Biota, Morocco. Geological Society, London, Special Publications, 485.

Gutiérrez-Marco, J.C., Muir, L.A. \& Mitchell, C.E. this volume $b$. Upper Ordovician planktic and benthic graptolites and a possible hydroid from the Tafilalt Biota, southeastern Morocco. In: Hunter, A.W., Álvaro, J.J., Lefebvre, B., VAN Roy, P. \& 
ZAMORA, S. (eds) The Great Ordovician Biodiversification Event: Insights from the

HARPER, D.A.T. 1982. The stratigraphy of the Drummuck Group (Ashgill), Girvan.

HavliceK, V. 1971. Brachiopodes de l'Ordovicien du Maroc. Notes et Mémoires du Service géologique du Maroc, 230, 1-135.

HoRnÝ, R.J. 1997. Ordovician Tergomya and Gastropoda (Mollusca) of the Anti-Atlas (Morocco). Sborník Národního Musea v Praze, 53, 37-78.

Hunter, A.W., Lefebvre, B., Nardin, E., Régnault, S., Van Roy, P., \& Zamora, S. 2010. Preliminary report on new echinoderm Lagerstätten from the Upper Ordovician of the eastern Anti-Atlas, Morocco. In: Harris, L.G., Böttger, S.A., WALKer, C.W. \& LesSer, M.P. (eds) Echinoderms: Durham. Balkema, Leiden, 23-30.

JAeKel, O. 1901. Ueber Carpoideen, eine neue Klasse von Pelmatozoen. Zeitschrift der Deutschen geologischen Gesellschaft, 52, 661-677.

JEFFERIES, R.P.S. 1990. The solute Dendrocystoides scoticus from the Upper Ordovician of Scotland and the ancestry of chordates and echinoderms. Palaeontology, 33, 631-679.

JefFeries, R.P.S. \& DALey, P.E.J. 1996. Calcichordates. In: HARPer, D.A.T. \& Owen, A.W. (eds), Fossils of the Upper Ordovician. The Palaeontological Association, London, 268276.

KerR, T.J.V. \& TwitchetT, R.J. 2004. Experimental decay and disarticulation of Ophiura texturata: implications for the fossil record of ophiuroids. In: HeINZELLER, T. \& NeBELsicK, J.H. (eds), Echinoderms: München. Balkema, Rotterdam, 439-446.

KLEIN, J.T. 1734. Naturalis dispositio Echinodermatum. Accessit lucubratiuncula de Aculeis Echinorum Marinorum, cum spicilegio de Belemnitis. Schreiber, Gedani, 79 p. 
670 Kolata, D.R. 1973. Scalenocystites strimplei, a new Middle Ordovician belemnocystitid 671 solute from Minnesota. Journal of Paleontology, 47, 969-974.

672 Kolata, D.R., Strimple, H.L. \& LeVerson, C.O. 1977. Revision of the Ordovician carpoid 673 family Iowacystidae. Palaeontology, 20, 529-557.

674 Lebrun, P. 2018. Fossiles du Maroc. Tome 1. Gisements emblématiques du Paléozoïque de 675 l'Anti-Atlas. Editions du Piat, Yssingeaux, 298 p.

676 LEFEBVRE, B. 2007a. Early Palaeozoic palaeobiogeography and palaeoecology of stylophoran 677 echinoderms. Palaeogeography, Palaeoclimatology, Palaeoecology, 245, 156-199.

678 LefebVRE, B. 2007b. Changes in Late Ordovician (pre-Hirnantian) echinoderm assemblages: 679 palaeoenvironmental and palaeobiogeographical implications. Acta Palaeontologica 680 Sinica, 46(suppl.), 241-248.

681

LefebVRe, B. \& FatKA, O. 2003. Palaeogeographical and palaeoecological aspects of the 682 Cambro-Ordovician radiation of echinoderms in Gondwanan Africa and peri-Gondwanan Europe. Palaeogeography, Palaeoclimatology, Palaeoecology, 195, 73-97.

684 685 686 687 688 689 690 691 692 693

LEFEBVRE, B. \& LEROSEY-AubriL, R. 2018. Laurentian origin of solutan echinoderms: new evidence from the Guzhangian (Cambrian Series 3) Weeks Formation of Utah, USA. Geological Magazine, 155, 1190-1204.

Lefebvre, B., Nardin, E., Hunter, A.W. \& RéGnault, S. 2007. Les échinodermes de l'Ordovicien supérieur de l'Anti-Atlas (Maroc): biostratigraphie et paléobiodiversité. Africa Geoscience Review, 14, 123-148.

Lefebvre, B., Noailles, F., Hunter, A.W., Nardin, E., RÉgnault, S., Franzin, B., Van Roy, P. \& El Hariri, K. 2008. Les niveaux à échinodermes de Bou Nemrou, un gisement à préservation exceptionnelle de l'Ordovicien supérieur du Tafilalt occidental (Maroc). Mésogée, 64, 7-25. 
Lefebvre, B., Noailles, F., Franzin, B., Régnault, S., Nardin, E., Hunter, A.W., ZAMOra, S., VAN Roy, P., El Hariri, K. \& LAZReQ, N. 2010. Les gisements à échinodermes de l'Ordovicien supérieur de l'Anti-Atlas oriental (Maroc): un patrimoine scientifique exceptionnel à préserver. Bulletin de l'Institut Scientifique, Rabat, 32, 1-17.

Lefebvre, B., Derstler, K. \& Sumrall, C.D. 2012. A reinterpretation of the solute Plasiacystis mobilis (Echinodermata) from the Middle Ordovician of Bohemia. In: Kroh A. \& Reich M. (eds.), Echinoderm research 2010: Proceedings of the Seventh European Conference on Echinoderms, Göttingen, Germany, 2-9 October 2010. Zoosymposia, 7, $287-306$.

Lefebvre, B., Sumrall, C.D., Shroat-Lewis, R.A., Reich, M., Webster, G.D., Hunter, A.W., Nardin, E., Rozhnov, S.V., Guensburg, T.E., Touzeau, A., NoAilles, F. \& Sprinkle, J. 2013. Palaeobiogeography of Ordovician Echinoderms. In: Harper, D.A.T. \& Servais, T. (eds) Early Palaeozoic Biogeography and Palaeobiogeography. Geological Society, London, Memoirs, 38, 165-190.

Lefebvre, B., Allaire, N., Guensburg, T.E., Hunter, A.W., Kouraïss, K., Martin, E.L.O., Nardin, E., Noailles, F., Pittet, B., Sumrall, C.D. \& Zamora, S. 2016. Palaeoecological aspects of the diversification of echinoderms in the Lower Ordovician of central Anti-Atlas, Morocco. Palaeogeography, Palaeoclimatology, Palaeoecology, 460, $97-121$.

Lefebvre, B., Guensburg, T.E., Martin, E.L.O., Mooi, R., NArdin, E., Nohejlová, M., SAleh, F., Kouraïss, K., El Hariri, K. \& David, B. 2019. Exceptionally preserved soft parts in fossils from the Lower Ordovician of Morocco clarify stylophoran affinities within basal deuterostomes. Geobios, 52, 27-36.

Lefebvre B., Nohejlová, M., Martin, E.L.O., KašičKa, L., Zicha, O. \& GutiérrezMARCO, J.C. this volume. New Middle and Late Ordovician cornute stylophorans 
(Echinodermata) from Morocco and other peri-Gondwanan areas. In: HunTER, A.W., Álvaro, J.J., Lefebvre, B., Van Roy, P. \& Zamora, S. (eds) The Great Ordovician Biodiversification Event: Insights from the Tafilalt Biota, Morocco. Geological Society, London, Special Publications, 485.

MacGabhann, B.A. 2012. A solution to Darwin's dilemma: differential taphonomy of Palaeozoic and Ediacaran non-mineralised discoidal fossils. Unpublished $\mathrm{PhD}$ thesis, Earth and Ocean Sciences, National University of Ireland, Galway, Ireland, 1, 657 p.

MEYeR, D.L. 1971. Post-mortem disintegration of Recent crinoids and ophiuroids under natural conditions. Geological Society of America Abstracts with Programs, 3, 645-646.

NARDIN, E. 2007. New occurrence of the Ordovician eocrinoid Cardiocystites: Palaeogeographical and palaeoecological implications. Acta Palaeontologica Polonica, 52, $17-26$.

NARdin, E., \& RÉGnAUlt, S. 2015. Palaeoecology of Ascocystites-dominated assemblages (Echinodermata, Blastozoa, Eocrinoidea) from the Upper Ordovician of the Moroccan Anti-Atlas. In: ZAMORA, S. \& RÁBAnO, I. (eds) Progress in Echinoderm Palaeobiology. Cuadernos del Museo Geominero, 19, 109-114.

NArdin, E., Lefebvre, B., DAVID, B. \& Mooi, R. 2009. La radiation des échinodermes au Paléozoïque inférieur, l'exemple des blastozoaires. Comptes-Rendus Palevol, 8, 179-188.

NoAilles-Gobry F. 2008. Les solutes (Echinodermata, Blastozoa) de l'Ordovicien supérieur de l'Anti-Atlas oriental (Maroc) : paléoécologie, ontogénie, diversité, affinités et implications paléogéographiques. Unpublished Master 2 thesis, Université Lyon 1, Villeurbanne, 45 p.

NoAilles, F., LefeBVRe, B. \& KAŠIČKA, L. 2014. A probable case of heterochrony in the solutan Dendrocystites Barrande, 1887 (Echinodermata: Blastozoa) from the Upper 
Ordovician of the Prague Basin (Czech Republic) and a revision of the family Dendrocystitidae Bassler, 1938. Bulletin of Geosciences, 89, 451-476.

745

NoheJlovÁ, M., \& FATKA, O. 2016. Ontogeny and morphology of Cambrian eocrinoid Akadocrinus (Barrandian area, Czech Republic). Bulletin of Geosciences, 91(1), 141-153.

Nohejlová, M., Lefebvre, B., Nardin, E., FatKa, O., \& Budil, P. 2019. New echinoderm Lagerstätte from the Letná Formation (Sandbian, Upper Ordovician) of Bohemia. In: Rozhnov, S.V., Dgebuadze, P.Yu. \& Mirantsev G.V. (eds) Abstracts of $10^{\text {th }}$ European Conference on Echinoderms, - Borissiak Paleontological Institute RAS, Moscow, 69.

PARSLEY, R.L. 1972. The Belemnocystitidae: solutan homeomorphs of the Anomalocystitidae. Journal of Paleontology, 46, 341-347.

PARSLEY, R.L., 1997. The echinoderm classes Stylophora and Homoiostelea: non Calcichordata. In: WATERs, J.A. \& MAPLes, C.G. (eds) Geobiology of Echinoderms. Paleontogical Society Papers, 3, 225-248.

PARSLEY, R.L. 2009. Morphology, ontogeny, and heterochrony in Lower and Middle Cambrian gogiids (Eocrinoidea, Echinodermata) from Guizhou Province, China. Paleontological Journal, 43, 1406-1414.

PARSLEY, R.L. 2012. Ontogeny, functional morphology, and comparative morphology of lower (Stage 4) and basal middle (Stage 5) Cambrian gogiids, Guizhou Province, China. Journal of Paleontology, 86, 569-583.

PARSLEy, R.L., \& CASTER, K.E. 1965. North American Soluta (Carpoidea, Echinodermata). Bulletins of American Paleontology, 49, 109-174.

PARSLEY, R.L., \& SumRALL, C.D. 2007. New recumbent echinoderm genera from the Bois d'Arc Formation: Lower Devonian (Lochkovian) of Coal County, Oklahoma. Journal of Paleontology, 81, 1486-1493. 
PARSLEY, R.L., Rozhnov, S.V. \& SumRaLL, C.D. 2012. Morphologic and systematic revision of the solute Maennilia estonica (Homoiostelea, Echinodermata) from the Upper Ordovician of Estonia. Journal of Paleontology, 86, 462-469.

Prokop, R.J., \& Petr, V. 2003. Plasiacystis mobilis, gen. et sp. n., a strange "carpoid" (Echinodermata, ?Homoiostelea: Soluta) in the Bohemian Ordovician (Czech Republic). Sborník Narodního Muzea, Serie B, Př́rodni vědy, 59, 151-162.

RAHMAN, I.A. \& LinTZ, H. 2012. Dehmicystis globulus, an enigmatic solute (Echinodermata) from the Lower Devonian Hunsrück Slate, Germany. Paläontologische Zeitschrift, 86, 5970.

Regnault, S. 2007. Occurrence of the genus Ascocystites Barrande (Echinodermata, Blastozoa) in the Upper Ordovician of the Anti-Atlas (Morocco). Annales de Paléontologie 93, 215-227.

RozhnOV, S.V., \& JEFFERIES, R.P.S. (1996). A new stem-chordate solute from the Middle Ordovician of Estonia. Geobios, 29, 91-109.

Service Geologique du Maroc. 1986. Carte géologique du Maroc : Tafilalt - Taouz. Echelle 1/200 000. Notes et Mémoires du Service géologique du Maroc, 244.

Service Geologique du Maroc. 1988. Carte géologique du Maroc : Todrha - Ma'der (AntiAtlas oriental, zones axiale et périphérique Nord et Sud). Echelle 1/200 000. Notes et Mémoires du Service géologique du Maroc, 243.

SMITH, A.B. 2005. The pre-radial history of echinoderms. Geological Journal, 40, 255-280.

SprinkLE, J. 1973. Morphology and Evolution of Blastozoan Echinoderms. Museum of Comparative Zoology Harvard University, Cambridge (Massassuchetts), 283 pp.

Sprinkle, J. \& GuensburG, T.E. 2004. Crinozoan, blastozoan, echinozoan, asterozoan, and homalozoan echinoderms. In: Webby, B.D., Paris, F., Droser, M.L. \& Percival, I.G. 

York, 266-280.

793

SumRALL, C.D. \& ZAMORA, S. this volume. New Upper Ordovician edrioasteroids from Morocco. In: Hunter, A.W., Álvaro, J.J., Lefebvre, B., Van Roy, P. \& Zamora, S. (eds) The Great Ordovician Biodiversification Event: Insights from the Tafilalt Biota, Morocco. Geological Society, London, Special Publications, 485.

Termier, H. \& Termier, G. 1970. Un échinoderme encroûtant de l'Ashgill (Ordovicien supérieur) du Tafilalt (Sud marocain): Herpetocystis destombesi nov. gen. nov. sp. Comptes rendus hebdomadaires des séances de l'Académie des Sciences, 271, 1260-1263.

Thoral, M. 1935. Contribution à l'Etude Paléontologique de l'Ordovicien inférieur de la Montagne Noire et Révision Sommaire de la Faune Cambrienne de la Montagne Noire. Imprimerie de la Charité, Montpellier, 362 p.

UBAGHS, G. 1969. Les Echinodermes «Carpoïdes» de l'Ordovicien inférieur de la Montagne Noire (France). Editions du CNRS, Cahiers de Paléontologie, 110 p.

Ubaghs, G. \& Robison, R.A. 1985. A new homoiostelean and a new eocrinoid from the Middle Cambrian of Utah. University of Kansas Paleontological Contributions, 115, 1-24.

UbAghs, G. \& Robison, R.A. 1988. Homalozoan echinoderms of the Wheeler Formation (Middle Cambrian) of western Utah. University of Kansas Paleontological Contributions, $120,1-17$.

Van Iten, H., Gutiérrez-Marco, J.C., Muir, L., Simões, M.G. \& Leme, M. this volume. Ordovician conulariids (Scyphozoa) from the Upper Tiouririne Formation (Katian), eastern Anti-Atlas Mountains, southern Morocco. In: Hunter, A.W., Álvaro, J.J., Lefebvre, B., VAn Roy, P. \& Zamora, S. (eds) The Great Ordovician Biodiversification Event: Insights from the Tafilalt Biota, Morocco. Geological Society, London, Special Publications, 485. 
VAn Roy, P.H.J. 2006. Non-Trilobite Arthropods from the Ordovician of Morocco. Unpublished Ph.D. thesis, Ghent University, Ghent, 230 p.

Villas, E. \& Colmenar, J. this volume. Brachiopods from the Upper Ordovician of Erfoud (eastern Anti-Atlas, Morocco) and the stratigraphic correlation of the bryozoan-rich Khabtel Hajar Formation. In: Hunter, A.W., Álvaro, J.J., Lefebvre, B., VAn Roy, P. \& ZAMORA, S. (eds) The Great Ordovician Biodiversification Event: Insights from the Tafilalt Biota, Morocco. Geological Society, London, Special Publications, 485.

Vinther, J., VAn Roy, P. \& BriggS, D.E.G. 2008. Machaeridians are Palaeozoic armoured annelids. Nature, 451, 185-188.

Zamora, S. \& Sumrall, C.D. this volume. The first report of coronates (echinodermata) from Africa. In: Hunter, A.W., Álvaro, J.J., Lefebvre, B., Van Roy, P. \& Zamora, S. (eds) The Great Ordovician Biodiversification Event: Insights from the Tafilalt Biota, Morocco. Geological Society, London, Special Publications, 485.

ZAMORA, S., DARRoch, S.A.F. \& RAHMAN, I.A. 2013a. Taphonomy and ontogeny of early pelmatozoan echinoderms: a case study of a mass mortality assemblage of Gogia from the Cambrian of North America. Palaeogeography, Palaeoclimatology, Palaeoecology, 377, $62-72$.

Zamora, S., Zhu, X. \& Lefebvre, B. 2013b. A new Furongian (Cambrian) EchinodermLagerstätte from the Sandu Formation (South China). Cahiers de Biologie Marine, 54, $565-569$.

Zamora, S., NArdin, E., Esteve, J., \& GutierreZ-Marco, J.C. this volume. New rhombiferan blastozoans (Echinodermata) from the Late Ordovician of Morocco. In: Hunter, A.W., Álvaro, J.J., Lefebvre, B., Van Roy, P. \& Zamora, S. (eds) The Great Ordovician Biodiversification Event: Insights from the Tafilalt Biota, Morocco. Geological Society, London, Special Publications, 485. 
Zhu, X.J., Peng, S., Zamora, S., Lefebvre, B. \& Chen, G. 2016. Furongian (upper Cambrian) Guole Konservat-Lagerstätte from South China. Acta Geologica Sinica, 90, $801-808$.

\section{Figure captions}

Fig. 1. (a) Simplified geological map of the Moroccan Anti-Atlas, showing the distribution of Ordovician rocks. (b) Simplified geological map of the region between Erfoud and Alnif (i.e. area covered by the two 1:200.000 geological maps of Todrha-Maïder and Tafilalt-Taouz) showing the position of solutan localities and the distribution of Ordovician rocks.

Fig. 2. Range and distribution of Late Ordovician solutan echinoderms from the western Tafilalt area, Morocco. The stratigraphy is based on Álvaro et al. (this volume).

Fig. 3. Dendrocystites aff. sedgwicki Barrande, 1867 from the Upper Ordovician Lower Ktaoua Formation (Anti-Atlas, Morocco). (a) Three large ('gerontic morphotype') specimens; ML20.269424, Tizi n'Mourghi (ECR-F1). (b) Accumulation of medium-sized ('adult morphotype') specimens; AA.JTK.OS.1, Jbel Taklimt (ECR-F9). All photographs are from latex casts whitened with $\mathrm{NH}_{4} \mathrm{Cl}$. Scale bar represents $1 \mathrm{~cm}$.

Fig. 4. Small ('juvenile morphotype') specimens of Dendrocystites aff. sedgwicki Barrande, 1867 from the Upper Ordovician Lower Ktaoua Formation (Anti-Atlas, Morocco). (a) Specimen with rounded theca; MHNN.P.045601, Piste de Jorf (ECR-F3). (b) Specimen with cordiform theca; MHNN.P.045611, Piste de Jorf (ECR-F3). (c) Specimen with cordiform 
864

865

866

867

868

869

870

871

872 Fig. 6. Large ('gerontic morphotype') specimens of Dendrocystites aff. sedgwicki Barrande, 8731867 from the Upper Ordovician Lower Ktaoua Formation (Anti-Atlas, Morocco); all from 874 Tizi n'Mourghi (ECR-F1). (a) ML20.269420. (b) ML20.269435. (c) ML20.269419. (d) 875 876

877

878 Fig. 7. Dendocystites barrandei Bather, 1913 and Homocystites sp. from the Upper 879 Ordovician Letná Formation (Sandbian, Barrandian Area). The photograph is from latex cast 880 881

theca; ML20.269428, Tizi n'Mourghi (ECR-F1). All photographs are from latex casts whitened with $\mathrm{NH}_{4} \mathrm{Cl}$. Scale bar represents $1 \mathrm{~cm}$.

Fig. 5. Medium-sized ('adult morphotype') specimens of Dendrocystites aff. sedgwicki Barrande, 1867 from the Upper Ordovician Lower Ktaoua Formation (Anti-Atlas, Morocco); all from Tizi n'Mourghi (ECR-F1). (a) ML20.269425. (b) ML20.269429. (c) ML20.269442. All photographs are from latex casts whitened with $\mathrm{NH}_{4} \mathrm{Cl}$. Scale bar represents $1 \mathrm{~cm}$.

ML20.269440. (e) ML20.269450. All photographs are from latex casts whitened with $\mathrm{NH}_{4} \mathrm{Cl}$. Scale bar represents $1 \mathrm{~cm}$. whitened with $\mathrm{NH}_{4} \mathrm{Cl}$. Scale bar represents $1 \mathrm{~cm}$. 